\title{
Navigating the Non-Native Planting Rule: Permit Requirements for Large-Scale Plantings of Non-Native Species in Florida'
}

\author{
Deah Lieurance, Eric Rohrig, and Stephen Enloe ${ }^{2}$
}

Agriculture is a multi-billion-dollar industry critical to Florida's economy that is dependent upon the cultivation of non-native species. As traditional crops such as citrus and avocado become increasingly difficult to produce due to pest and disease issues, interest in alternative crops grown for biofuel, fiber, and other biomass purposes is on the rise. While alternative crops may hold great promise for Florida's economy, there are legitimate concerns regarding their potential invasiveness, especially those being developed for biomass production. Many of the non-native species under consideration for biomass planting share several important biological traits (e.g., high biomass and seed productivity, quick time to maturity, and tolerance and resistance to adverse conditions) with invasive plant species. Because invasive species have detrimental impacts to Florida's natural areas, are costly to Florida's economy, and in some cases, harmful to Floridians' health, special measures have been implemented to prevent the escape of potentially invasive species from production areas. The purpose of the Non-Native Species Planting Permits Rule (Florida Administrative Code, 5B-57.011 Chapter 581.083, 2020) is to "control the introduction into, or movement within, Florida of a plant species intended for plantings greater than two contiguous acres." This fact sheet discusses why plantings of non-native plants are regulated, describes how plantings are regulated in Florida, and shows how the UF/ IFAS Assessment of Non-Native Plants in Florida's Natural Areas is critical to this process.

\section{Why Plantings of Non-Native Plants Are Regulated}

A non-native species is defined as a species (or subspecies, cultivar, selection, etc.) introduced (intentionally or accidentally) outside its natural past or present distribution that does not occur naturally in a specified geographic area. An invasive species is a non-native species introduced by humans that causes (or is likely to cause) economic or environmental harm or harm to human health. Not all non-native species become invasive. However, some introduced species do become invasive, leading to high management costs and significant environmental impacts to natural areas which result in economic losses. Globally, approximately one million species are in danger of going extinct. Invasive species have been identified as one of the five major drivers of this decline in biodiversity (Diaz et al. 2019). Environmental impacts such as reduced native plant diversity, reduced tree regeneration, altered fire and hydrologic regimes, and altered carbon and nitrogen cycling have been quantified for many invasive plants. Florida is particularly vulnerable to non-native invasive species because of its tropical/subtropical climate, peninsular geography, and unique ecosystems. Half of Florida's land area is estimated to be in development or used for agriculture (Enloe and Langeland 2018). Florida's natural areas are crucial to preserving rare, threatened, or endangered

1. This document is SS-AGR-453, one of a series of the Agronomy Department, UF/IFAS Extension. Original publication date June 2021. Visit the EDIS website at https://edis.ifas.ufl.edu for the currently supported version of this publication.

2. Deah Lieurance, assistant Extension scientist, UF/IFAS Center for Aquatic and Invasive Plants; Eric Rohrig, Florida Department of Agriculture and Consumer Services, Division of Plant Industry; and Stephen Enloe, professor, UF/IFAS CAIP; UF/IFAS Extension, Gainesville, FL 32611.

The Institute of Food and Agricultural Sciences (IFAS) is an Equal Opportunity Institution authorized to provide research, educational information and other services

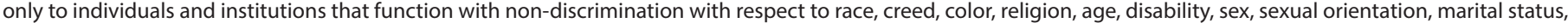

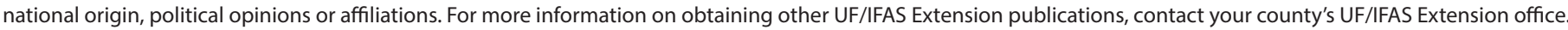
U.S. Department of Agriculture, UF/IFAS Extension Service, University of Florida, IFAS, Florida A \& M University Cooperative Extension Program, and Boards of County Commissioners Cooperating. Nick T. Place, dean for UF/IFAS Extension. 
species native and confined to the state, including the Key deer (Odocoileus virginianus clavium), Perdido Key beach mouse (Peromyscus polionotus trissyllepsis), Schaus' swallowtail butterfly (Heraclides aristodemus), and pygmy fringe tree (Chionanthus pygmaeus). Additionally, the cost of managing invasive plants on Florida's conservation lands and waters alone average approximately $\$ 45$ million annually (Hiatt et al. 2019), and control costs statewide may approach $\$ 100$ million per year (The Nature Conservancy 2020).

Concerns have been expressed about the potential invasiveness of energy crops (Figure 1). The National Invasive Species Council has recommended that the federal government take steps to minimize the invasion risk of biofuel crops. These recommendations include the following:

- Review/strengthen existing authorities

- Reduce escape risks

- Determine the most appropriate areas for cultivation

- Identify plant traits that contribute to invasiveness

- Prevent dispersal

- Establish eradication protocols for rotational systems or abandoned populations

- Develop and implement early detection and rapid response plans and rapid response funding

- Minimize harvest disturbance

- Engage stakeholders (Ditomaso et al. 2010)

Although these recommendations were outlined specifically for biofuel species, they are also applicable to all non-native biomass planting.

\section{How Plantings of Non-Native Plants Are Regulated in Florida}

\section{The Rule}

\section{B-57.011 NON-NATIVE SPECIES PLANTING PERMITS}

"(1) In accordance with Section 581.083, F.S., a person may not cultivate non-native plants, algae, or blue-green algae, including genetically engineered plants, algae, or blue-green algae in plantings greater in size than two contiguous acres, except under a Non-Native Species Permit issued by the Department's Division of Plant Industry. Anyone seeking a Non-Native Species Permit shall submit a completed Non-Native Species Planting Permit Application, FDACS 08381 (Rev. 01/13), to the Division of Plant Industry, P. O.
Box 147100, Gainesville, FL 32614-7100” (section 581.083 (4), F.S.).

In simpler terms, if you wish to plant two or more connected acres of a non-native plant in the state of Florida, you must submit a permit application to the state. Applications can be found online at http://forms.freshfromflorida. com/08381.pdf. In this petition, the applicant must provide information regarding the species to be planted, location and size of plantings, containment methods to prevent inadvertent spread, and an estimate of the cost to remove and destroy the planting. Applicants are required to submit a cover letter (letter of intent) and a $\$ 50$ non-refundable fee with each application. A separate application is required for each tract of land. Applications for a permit are sent to the Bureau of Methods Development and Biological Control, Division of Plant Industry, P.O. Box 147100, Gainesville, FL 32614-7100. Once submitted to FDACS, the Division of Plant Industry (DPI) reviews the application and a site visit is scheduled.

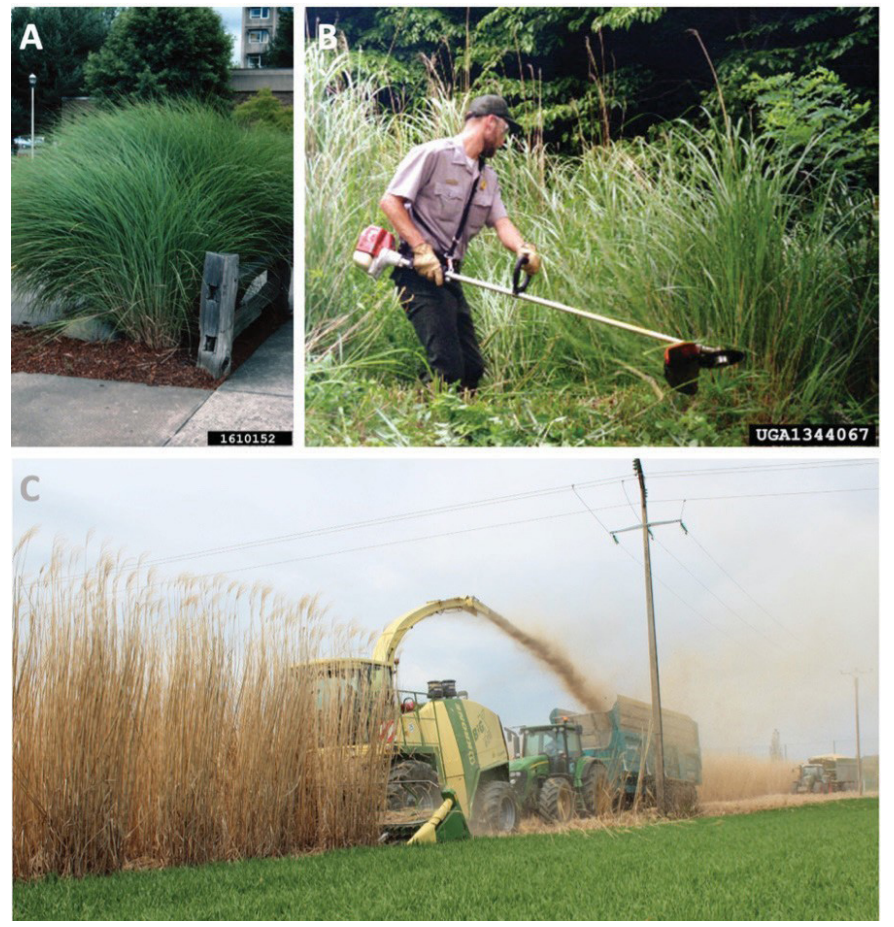

Figure 1. Miscanthus spp. were originally introduced to the United States as a landscaping or ornamental species (A). Some species of Miscanthus including Chinese silvergrass (M. sinensis) invade roadsides, forest edges, and other disturbed areas (B). Miscanthus species and varieties such as Miscanthus $x$ giganteus are currently in production in the United States as perennial biomass crops (C). Credits: John Ruter, Bugwood; USDI National Park Service, Bugwood; Hamsterdancer, CC BY-SA 3.0, via Wikimedia Commons.

Congruently, DPI also works with the UF/IFAS Assessment of Non-Native Plants in Florida's Natural Areas (hereafter, the UF/IFAS Assessment) to determine if the proposed plant presents a risk of becoming an invasive species. The 
UF/IFAS Assessment conducts weed risk assessment, or a science-based evaluation of the potential of a plant species to establish, spread, and cause harm in the state. At this point, the application can be 1) rejected if the risk for invasion is too high, 2) permitted and monitored with specified best management practices defined and a surety bond for eradication deposited, or 3) be exempted from permitting, if the species does not present a significant invasion risk. See the "Exemptions" section below for other situations where a permit is not required.

Questions regarding the DPI Non-Native Planting Permit should be directed to: Dr. Eric Rohrig, Bureau Chief, Methods Development and Biological Control, Division of Plant Industry, Florida Department of Agriculture and Consumer Services, Eric.Rohrig@FDACS.gov.

\section{Best Management Practices}

Generally, best management practices for cultivating non-native plants should minimize the risk of escapes throughout the supply chain (planting and production, harvest, transport, storage, and processing) (Barney 2012). Figure 2 illustrates some practices that should be avoided including viable propagules (seeds) on production machinery $(\mathrm{A}-\mathrm{C})$ and nursery waste containing viable propagation materials such as rejected rootstock and seed. To reduce escape from permitted plantings, FDACS may require a system of traps or filters to prevent plants or plant parts (seeds and vegetation) from spreading through ditches, natural waterways, or other drainage. A buffer greater than 25 feet is required to prevent spread to adjacent areas and can also be supplemented with a berm surrounding the biomass planting (Figure 3). Any equipment used on the site must be cleaned of all plant debris before being moved from the property. Wildfire protection measures must also be implemented to mitigate fire risk and damages to surrounding areas. Additionally, other measures can be required to prevent spread at all stages of production on a case-by-case basis.

\section{Surety Bond}

For each separate growing location, permit holders must maintain a bond or a certificate of deposit in an amount of not less than 1.5 -fold the estimated cost of removing and destroying the plants. If a biomass planting is abandoned, the permit holder or property owner must completely destroy the planting. Execution of the bond or $\mathrm{CD}$ will be used, if deemed necessary by FDACS, to destroy the crop. Consider the surety bond a down payment on the estimate to remove and destroy the planting. Generally, the surety bond is around $10 \%$ of the total estimated amount
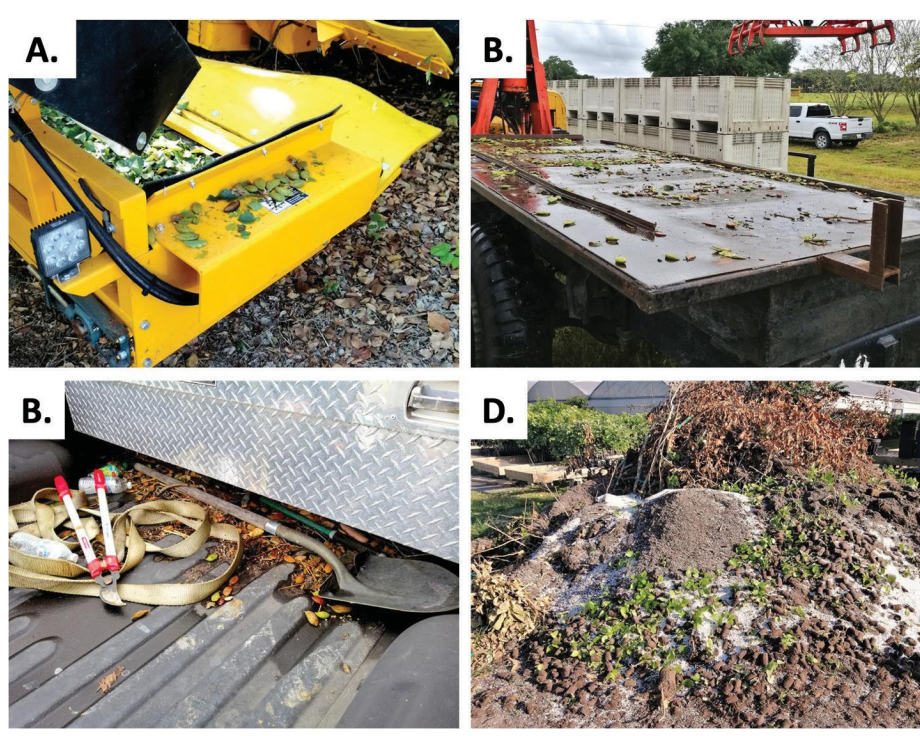

Figure 2. Machinery used during harvest and pruning accumulating loose seeds which may escape during transport $(A-C)$ and nursery waste containing viable propagation materials such as rejected rootstock and seed (D).

Credits: Michael Sthreshley, UF/IFAS

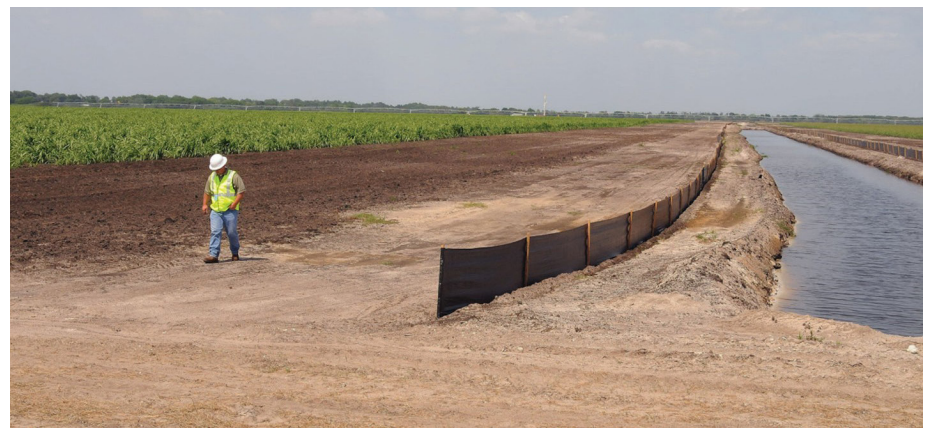

Figure 3. Bare earth buffer and silt fence that were implemented to contain hundred+ acre Napier grass (Pennisetum purpureum) planting in Lorida, Florida.

Credits: Trevor Smith, Florida Department of Agriculture and Consumer Services, Division of Plant Industry

to eradicate. For example, a $\$ 1,000$ bond will only cost the applicant approximately $\$ 100$ per year. Bond or CD requirements are detailed in the Biomass Rule 5B-57.011 F.A.C. and Statute 581.083 F.S.

\section{Exemptions}

In addition to the exemptions for low-invasion risk species (as determined by the UF/IFAS Assessment), plants produced for purposes of food consumption, plants commonly grown for commercial feed, feedstuff, or forage for livestock, and pine trees (Pinus spp.) are also exempted. These exemptions are currently interpreted on a case-bycase basis by DPI.

FDACS does not require a permit for the following: 
- Any plant that is commonly grown in Florida for purposes of human food consumption

- Any plant that is commonly grown in Florida for commercial feed, feedstuff, or forage for livestock, nursery stock, or silviculture

- Aquatic plants, algae, or blue-green algae grown in compliance with Aquaculture Best Management Practices and certified by the Division of Aquaculture pursuant to Section 597.004, F.S.

- Cyanobacterium sp. (Strain ABI)

- Energy cane (complex hybrid of Saccharum officinarum, S. spontaneum, S. barberi, and S. sinense)

- Eucalyptus amplifolia

- Eucalyptus benthamii

- Eucalyptus dorrigoensis

- Eucalyptus dunnii

- Eucalyptus grandis

- Eucalyptus gunni

- Eucalyptus nitens

- Eucalyptus smithii

- Eucalyptus urograndis-E. grandis $x$ E. urophylla

- Hibiscus cannabinus L.

- Miscanthus giganteus-M. sacchariflorus x M. sinensis

- Pinus spp.

Note: With the exception of Miscanthus giganteus, importation of Saccharum and Miscanthus species requires a Non-Native Species Permit in accordance with Rule 5B-3.003, F.A.C.

\section{The UF/IFAS Assessment of Non-Native Plants in Florida's Natural Areas}

The UF/IFAS Assessment of Non-Native Plants in Florida's Natural Areas (hereafter, the UF/IFAS Assessment) uses literature-based assessment tools to evaluate and predict the invasion risk of non-native plant species. The goal of the UF/IFAS Assessment is to ensure that species with invasive characteristics are not recommended for use by UF/IFAS, thus decreasing the potential for invasion of those species into natural areas. The UF/IFAS Assessment is composed of three components: Status Assessment, Infraspecific Taxon Protocol (ITP), and Predictive Tool. The Predictive Tool is a weed risk assessment used to screen proposed non-native species for FDACS. The Predictive Tool is based on the Australian Weed Risk Assessment and was modified to fit Florida's climate, precipitation, and soil types.
Questions presented in the Predictive Tool are answered by conducting thorough literature searches, using sources such as herbaria records, agency reports, and peer-reviewed primary literature. The questions in the Predictive Tool address:

History of the species (i.e., domestication/cultivation)

- Biogeography (i.e., native range vs. proposed release sites, invasive status in other regions)

- Life history traits (i.e., plant type, growth habit, modes of reproduction)

- Ecology (i.e., persistence attributes, allelopathy, dispersal mechanisms)

Each question receives a numerical score between -3 and 5 points (most $-1,0$, or 1 ), and conclusions are made based on the cumulative score. There are three potential outcomes of the Predictive Tool:

- Low Risk ( $<1$ point)

- High Risk (>6 points)

- Moderate Risk/Evaluate further (between 1 and 6 points)

Thresholds for each conclusion were established by assessing known major invasive, minor invasive, and non-invasive plants. These thresholds prevent the introduction of many serious invasive species, limit the rejection of species that are not likely to become invasive, and limit the number of species requiring further evaluation (Pheloung, Williams, and Halloy 1999).

Typically, this tool is used to screen for invasion risk pre-introduction, but in the case of the Non-Native Planting Rule, this approach is used because production systems increase the number of individuals in the landscape and subsequently alter the risk for invasion. For example, a large-statured grass typically used for landscaping that is planted for biofuels may increase the number of plants from one or two individuals to hundreds or thousands in a system. For more information on the UF/IFAS Assessment, refer to The UF/IFAS Assessment of Nonnative Plants in Florida's Natural Areas: History, Purpose, and Use (https:// edis.ifas.ufl.edu/ag376) (Lieurance and Flory 2020). 


\section{References}

Barney, J. 2012. "Best Management Practices for Bioenergy Crops: Reducing the Invasion Risk." Virginia Cooperative Extension. Publication PPWS-8: 1-8. https://www.pubs. ext.vt.edu/content/dam/pubs_ext_vt_edu/PPWS/PPWS-8/ PPWS-8P-pdf.pdf

Diaz, S., J. Settele, E. Brondizio, H. Ngo, M. Guèze, J. Agard, A. Arneth, et al. 2019. "Summary for Policymakers of the Global Assessment Report on Biodiversity and Ecosystem Services of the Intergovernmental Science-Policy Platform on Biodiversity and Ecosystem Services." https://www. ipbes.net/sites/default/files/downloads/spm_unedited_advance_for_posting_htn.pdf

Ditomaso, J. M., J. K. Reaser, C. P. Dionigi, O. C. Doering, E. Chilton, J. D. Schardt, and J. N. Barney. 2010. "Biofuel vs. Bioinvasion: Seeding Policy Priorities." Environmental Science Technology 44:6906-6910. https://doi.org/10.1021/ es100640y

Enloe, S. F., and K. A. Langeland. 2018. Help Protect Florida's Natural Areas from Non-Native Invasive Plants. Circular 1204. Gainesville: University of Florida Institute of Food and Agricultural Sciences. https://edis.ifas.ufl.edu/ publication/ag108

Florida Administrative Code. 2020. "Non-Native Species Planting Permits." Chapter 581.083, Florida Statute and Rule 5B-57.011.

Hiatt, D., K. Serbesoff-King, D. Lieurance, D. R. Gordon, and S. L. Flory. 2019. "Allocation of Invasive Plant Management Expenditures for Conservation: Lessons from Florida, USA." Conservation Science and Practice 1:e51. https://doi. org/10.1111/csp2.51

Lieurance, D., and S. L. Flory. 2020. The UF/IFAS Assessment of Nonnative Plants in Florida's Natural Areas: History, Purpose, and Use. SS-AGR-371. Gainesville: University of Florida Institute of Food and Agricultural Sciences. https:// edis.ifas.ufl.edu/publication/ag376

The Nature Conservancy. 2020. Stopping the Spread of Invasive Species. Arlington, VA. https://www.nature.org/ en-us/about-us/where-we-work/united-states/florida/ stories-in-florida/combating-invasive-species-in-florida/

Pheloung, P. C., P. A. Williams, and S. R. Halloy. 1999. "A Weed Risk Assessment Model for Use as a Biosecurity Tool Evaluating Plant Introductions." Journal of Environmental Management 57:239-251. https://doi. org/10.1006/jema.1999.0297

\section{Glossary}

Non-native species planting: The cultivation or production of a non-native plant, algae, or blue-green algae, including a genetically engineered plant, algae, or blue-green algae in plantings.

Non-native species: A species (or subspecies, cultivar, selection, etc.) introduced (intentionally or accidentally) outside its natural past or present distribution.

Surety bond: A promise to be liable for the debt, default, or failure of another. It is a three-party contract by which one party (the surety) guarantees the performance or obligations of a second party (the principal) to a third party (the obligee).

Contiguous acre: Defined as plantings of non-native plants with a common boundary or a parcel of land that has been separated or divided into more than one planting of nonnative plants whether separated or divided by a roadway or any other area not under cultivation with non-native plants.

Invasive plant (state definition): A naturalized plant that disrupts naturally occurring native plant communities by altering structure, composition, natural processes, or habitat quality.

Noxious weed (state definition): Any living stage, including but not limited to seeds and reproductive parts, of a parasitic or other plants of a kind, or subdivision of a kind, which may be a serious agricultural threat in Florida, or have a negative impact on the plant species protected under Section 581.185, F.S., or if the plant is a naturalized plant, that disrupts naturally occurring native plant communities. 